\title{
(B) (代idte
}

bes

\section{$\mathfrak{E}$ I)}

eines

FindelEindes.

Mores hominum multorum vidie.

Sünfter Band.

มน beu Englifaen.

\section{feipfig,}

bey Georg Joadim Sifhen.

1788 



\author{
(Ge e f d i i d t $t \mathfrak{c}$ \\ Ses

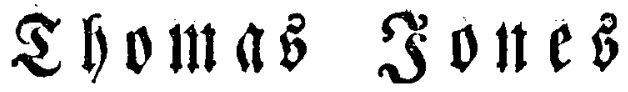 \\ eines \\ Findeleindes. \\ Şunffer $\mathfrak{B a n t}$
}

$\mathfrak{4} 2$ 
